\title{
Soluble Guanylate Cyclase
}

National Cancer Institute

\section{Source}

National Cancer Institute. Soluble Guanylate Cyclase. NCI Thesaurus. Code C20141.

Human Soluble Guanylate Cyclases (Adenylyl Cyclase 4/Guanylyl Cyclase Family) are heterodimeric (alpha/beta) nitric oxide-activated cytoplasmic enzymes that catalyze conversion of GTP to cGMP second messenger. The main receptors for nitric oxide in the cardiovascular system and for nitrovasodilator drugs, alpha/beta interaction is required for guanylyl cyclase activity. $(\mathrm{NCl})$ 